\title{
Impediments to Effective Teaching and Learning of Basic Technology in Nigerian Public Secondary Schools
}

\author{
${ }^{1}$ Elisha N. Elom. (P.hD) and ${ }^{2}$ Ugochukwu Chinonso Okolie. \\ ${ }^{1,2}$ Department of Technology and Vocational Education, Ebonyi State University, Abakaliki, Nigeria.
}

\begin{abstract}
The main purpose of this study was to find out the impediments to effective teaching and learning of basic technology in Nigerian Public Secondary Schools. The study adopted survey design and was conducted in twelve secondary schools in Ebonyi State Nigeria. Five (5) basic technology teachers and two (2) school administrators from each of the twelve schools selected were used for the study. Therefore, the total population of the study was sixty (60) basic technology teachers and twelve (12) school administrators, making the population a total of 84 people. There was no sample or sampling because, the population was small; so all were used for the study. The researcher with the help of research assistants conducted interviews with the school administrators and also administered questionnaires, which contained items for answering the research questions. Questionnaire was also the instrument for data collection. Data collected was analyzed using appropriate statistical procedures. Findings among others revealed that poor teaching methods adapted by basic technology teachers, inadequacy of instructional materials, inadequate workshop tools and equipment needed for effective teaching and learning of basic technology and poor funding of basic technology are the impediments to effective teaching and learning of basic technology in Nigerian public schools. Recommendations were made based on the results found.
\end{abstract}

Keywords: Basic Technology, Effective Teaching, Teaching and Learning, Secondary Schools

\section{Introduction}

Basic technology, which is one of the core subjects among the pre-vocational subjects of the junior secondary school, is made up of other subjects such as technical drawing, applied electricity, wood work, metal work, basic electronics and ceramic. It also involves academic practical study of materials and sources of energy with the ultimate intention of applying knowledge from the study to provide a comfortable environment for man (Onwuzuruigbo, 2007). The study of basic technology has helped to reduce ignorance of technology; it gives opportunity to students to use tools and machines that are used in the industrial process, it provides skills that help the learners to handle any piece of work given them. Also, students who have acquired basic technology knowledge and do not have means of continuing their education may be employed as craftsmen in industries. Uwameiya (2006) observed that through basic technology, students are assisted to explore the various areas of technology towards making intelligent career choice. Basic technology has three main objectives as stated by the Federal Republic of Nigeria (2004);

1. To provide pre-vocational orientation for further technology.

2. To provide basic technology literacy for every living

3. To stimulate creativity.

These objectives of the basic technology as stated by the Federal Republic of Nigeria will only be achieved if basic technology is effectively taught and learnt in the junior secondary classes and this will improve technological manpower in the country. According to Fafunwa (2001) the major goal of technology education is to prepare the students for productive work like participatory citizens, give them skills and knowledge so that all the attitudes the students acquired will be related to the needs and problems of their immediate environment. But the reverse has been the case in Nigerian public schools recently. It requires effective teaching of basic technology as well as proper management of the public schools to correct the abnormalities.

At the junior secondary school, students are expected to be exposed to fundamental skills needed to be relevant in the society. They are supposed to acquire skills in wood work, metal work, electrical and electronics and local crafts so that those who will leave the schools at the junior secondary school level will be fit in the world of work.

Teaching on the other hand, is the process of impacting knowledge, skill and attitude to the learners. It can also be seen as the process of transferring knowledge from one person (the teacher) to another (the learner) (Agwu, 2005). Teaching cannot be complete unless learning has taken place as a result of someone's effort (Teacher). According to Lin (2001), learning is the acquisition of cognitive process of acquiring skills, values, understanding and preference or knowledge. It leads to the development of new capabilities, understanding and preference. According to Nwani (2005), the learner is the central focus of the entire educational efforts because, he is the person that is been taught. 


\section{Statement of the Problem}

It has been observed in many public schools in Nigeria that the results of basic technology every year in the Junior Secondary School Certificate Examination (JSSCE) is not encouraging in spite of the efforts made to achieve basic technology objectives. This study was designed to determine what actually causes low achievement of basic technology objectives in public secondary schools. If students' poor performance in basic technology is allowed to continue, it will not only affect technological development in Nigeria, it will leave the junior secondary school leavers with no skills to be fit in the world of work. And this over time will affect Nigeria's income per capital negatively since poor industrialization leads to poor civilization.

\section{Purpose of the Study}

The main purpose of this study was to identify the impediments to effective teaching and learning of basic technology in Nigerian public junior secondary schools. Specifically, the study tends to;

1. Find out the teaching methods the teachers use for teaching and learning of basic technology.

2. Determine whether there are adequate instructional materials for teaching and learning of basic technology.

3. Determine the state of workshop tools and equipment for teaching and learning of basic technology.

4. Determine the extent of funding the teaching and learning of basic technology in public secondary schools.

\section{Significance of the Study}

The findings of this study will be beneficial to curriculum planners, teachers, students, government agencies, society and parents. The curriculum planners will make use of the findings during innovations; it'll assist them to ascertain how the set goals and objectives of the basic technology have been achieved and as well seek for improvements where necessary. The findings will assist basic technology teachers and school administrators to access their areas of weakness and work hard for improvement of their competencies. The study will also sensitize the government and other educational agencies especially the secondary school boards on the need to build adequate workshops and equip them in public secondary schools.

\section{Research Questions}

The study was designed answer the following research questions;

1. What are the suitable teaching methods adopted for effective teaching and learning of basic technology?

2. How adequate are the instructional materials for teaching and learning of basic technology in public Secondary Schools?

3. What are the state of workshop tools and equipment for teaching and learning basic technology in public secondary schools?

4. To what extent is the teaching and learning of basic technology in public secondary schools funded?

\section{Methodology}

The study adopted survey design and was conducted in twelve secondary schools in Ebonyi State Nigeria. The researcher selected five (5) basic technology teachers in each of the secondary schools used for the study and two (2) school administrators for the study. Therefore, the total population of the study was sixty (60) basic technology teachers and twelve (12) school administrators, making the population a total of 84 people. There was no sample or sampling because, the population was small; so all were used for the study. The researcher with the help of research assistants conducted interviews with the school administrators on the subject of study. Questionnaire, which contained items for answering the research questions, was the main instrument for data collection. The questionnaires were distributed to the study population by hand and collected the questionnaires after their response. The data collected were analyzed in a descriptive form.

\section{Findings/Discussions}

Research Question 1: What are the suitable teaching methods adopted for effective teaching and learning of basic technology?

Table 1

Mean response on the suitable teaching methods adopted in teaching and learning of basic technology. 


\begin{tabular}{|c|c|c|c|c|c|}
\hline Items & $X$ & Agree & $\%$ & Disagree & $\%$ \\
\hline $\begin{array}{l}\text { Students understands better when the } \\
\text { teacher uses demonstration methods to } \\
\text { teach in the classroom. }\end{array}$ & 84 & 71 & 84.52 & 13 & 15.48 \\
\hline $\begin{array}{l}\text { Teaching students with instructional } \\
\text { materials helps them to understand faster. }\end{array}$ & 84 & 63 & 75.00 & 21 & 25.00 \\
\hline $\begin{array}{l}\text { Students' visit to the industries exposes } \\
\text { them to life skills based learning of basic } \\
\text { technology. }\end{array}$ & 84 & 58 & 69.05 & 26 & 30.95 \\
\hline $\begin{array}{l}\text { Discussion method of teaching gives } \\
\text { students higher opportunities to ask } \\
\text { questions in the classroom. }\end{array}$ & 84 & 69 & 82.14 & 15 & 17.86 \\
\hline $\begin{array}{l}\text { Using lecture method of teaching makes it } \\
\text { easier for the students to understand } \\
\text { basic technology }\end{array}$ & 84 & 34 & 40.48 & 50 & 59.52 \\
\hline $\begin{array}{l}\text { Group method of teaching is suitable for } \\
\text { teaching and learning of basic technology. }\end{array}$ & 84 & 67 & 79.76 & 17 & 20.24 \\
\hline
\end{tabular}

Table 1 revealed the responses of the study population on the suitable teaching methods adopted in teaching and learning of basic technology. Meanwhile, method of teaching involves different ways of presenting subject matter to the learners (students). Ogwa (2002) defined teaching method as the vehicle to convey the objectives of a lesson in a way that the learner can acquire the required knowledge and skills at the end of the lesson. The study revealed that students understand better when the teacher uses demonstration methods to teach in the classroom. This is in line with Okoro (1993) that some teaching methods that need to be adopted in teaching basic technology subject in secondary schools are discussion method, project method, demonstration method, group teaching method and field trips. Since basic technology has both theoretical and practical orientation, there is need for integration of many resources and techniques to actualize the objectives of the subject as stated by the National Policy on Education.

Demonstration method of teaching is the most vivid and efficient teaching method that is used in basic technology subject (Ogwa, 2002). It is possible for students to learn how to perform by reading or being told how to do something. However, the students will learn faster and more effectively when they are shown something in the classroom because, the experience will stick in their memory. Demonstration is the presentation of planned action designed to illustrate a useful phenomena; it is often used to teach fundamental operations in basic technology. With demonstration method, the teacher can explain the steps of an operation of a practical while performing them. Through this teaching and learning process, students usually use two or more of the five senses. Demonstration is the most common teaching method that can be used where practical work is often carried out for skills acquisition.

The study also revealed that teaching students with instructional materials helps them to understand faster. This is in line with the Ogwa (2002) that instructional material is all the materials that the teacher utilizes for the purpose of making teaching and learning more effective and meaningful to the students. With the help of instructional materials, it will be easy for the basic technology teacher to communicate faster and better with the students. Examples of the instructional materials include; textbooks, chalkboard, pictorial drawings, raffia palm for cork clay, calabash for world globe, clips, switches etc. In many secondary schools, many of these instructional materials are not available and where available, they are inadequate. This results in teachers delivering their lessons without instructional materials; even most at times, basic technology is taught without any form of practical work. All this hinders students from effective learning and it makes them not to be creative and unproductive.

The respondents agreed that students' visit to the industries exposes them to life skills based learning of basic technology. This is in line with Inyiagu, (2012) that exposing the students to the industry is an effective method of instruction, which helps the students not only to acquire occupation oriented knowledge, skills and attitudes, but also to have the opportunity of applying the skills in the real world of work. He further stated that in this way, students have multiple benefits of instruction and supervision by the experienced industry based supervisor, the school's basic technology teacher

The study findings revealed that discussion method of teaching gives students higher opportunities to ask questions in the classroom. In demonstration method according to Ogwa (2002), the teacher moderates the students as they provide most of the information that the teacher draw upon from the experience of the class members. This method is different from lecture method where the teacher directly relates ideas and information to the students. The teacher also acts as a conference leader who moderates the students' discussions. Discussion methods are usually shared into large group's discussion, small groups' discussion and panel discussion. In large group, all the students in the classroom may discuss a topic under the guidance and direction of the teacher. The teacher will provide the topic and start the discussion; he/she will ask the students questions to enable the 
students fully participate in the topic of discussion after which he/she will summarize the opinion of the students.

Using lecture method of teaching makes it very difficult for basic technology students at the junior secondary school level to understand the teacher since this method does not give room for much explanation by the teacher. The study revealed that lecture method is not good for the basic technology students since the respondents disagreed with the questionnaire item. Also, group method of teaching is suitable for teaching and learning of basic technology as agreed by the study respondents. Ogwa, (2002) noted that this method enables the teacher to divide his/her class into small groups to handle an aspect of a topic; discuss the topic, summarizes it, conclude and as well present their findings in the class. Each of the small groups must provide tangible information for the entire class at the end of the discussion.

Research Question 2: How adequate are the instructional materials for teaching and learning of basic technology in public Secondary Schools?

Table 2

Mean response on the adequacy of instructional materials for teaching and learning of basic technology in public secondary schools.

\begin{tabular}{|c|c|c|c|c|c|}
\hline Items & $\mathrm{X}$ & Agree & $\%$ & Disagree & $\%$ \\
\hline $\begin{array}{l}\text { There are inadequate instructional } \\
\text { materials for teaching and learning of basic } \\
\text { technology in Nigerian public schools. }\end{array}$ & 84 & 73 & 86.90 & 11 & 13.09 \\
\hline $\begin{array}{l}\text { Many public secondary schools do not have } \\
\text { enough basic technology text books for } \\
\text { students. }\end{array}$ & 84 & 66 & 78.57 & 18 & 21.43 \\
\hline $\begin{array}{l}\text { Teachers sometimes borrow instructional } \\
\text { materials from other colleagues } \\
\text { in good private secondary schools during } \\
\text { lessons. }\end{array}$ & 84 & 62 & 73.80 & 22 & 26.19 \\
\hline $\begin{array}{l}\text { Due to lack of motivation, teachers hardly } \\
\text { improvise during teaching of basic technology }\end{array}$ & 84 & 59 & 70.24 & 25 & 29.76 \\
\hline $\begin{array}{l}\text { In most public secondary schools, the available } \\
\text { instructional materials are very few and } \\
\text { obsolete. }\end{array}$ & 84 & 75 & 89.29 & 09 & 10.71 \\
\hline
\end{tabular}

Table 2 shows the mean response on the adequacy of instructional materials for teaching and learning of basic technology in public secondary schools. From the statistical data presented, the result agreed to all the items that there are inadequate instructional materials for teaching and learning of basic technology in Nigerian public schools and many public secondary schools do not have enough basic technology text books for students. This is in line with the findings of Eya and Neboh (2001) that many public schools do not make much effort towards purchasing current text books for their students reading; some of the textbooks available in some of the schools inform of instructional materials are outdated and efforts are sometimes not made to improve the situation.

Eya and Neboh (2001) identified four major types of instructional materials the public schools need, which include: two dimensional materials, three dimensional materials, boards and audio/ audio-visual materials. Studis have shown that in most Nigeria schools, materials such as magnetic board, electric boards, and all the audio/ audio-visual materials like cassette recorder, tape-recorded materials, radio, projectors, film strips, slides, transparencies, television and video recorders are not available and where they are provided, they are inadequate (Eya, 2006). The study further revealed that basic technology teachers in public schools sometimes borrow instructional materials from other colleagues in good private secondary schools during lessons. This is in line with the findings of Okolie (2014) that many technical teachers sometimes borrow teaching materials from road side mechanics.

The study revealed that due to lack of motivation, teachers hardly improvise during teaching of basic technology. Ekemede, (2005) stated that it has become a culture in the Nigerian educational system to owe teachers monthly salary. When teachers are not paid, they are not motivated; and when they are not motivated, they cannot improvise; the students suffer the consequences. The respondents agreed that in most public secondary schools, the available instructional materials are very few and obsolete. Eya (2006) stated that the old form of instructional materials, which include chalkboard, graph, charts, posters, realia, specimen etc. have been part of public schools but the new forms of instructional materials, which include the use of radio, the radiocassette, the television, the overhead projection, the slide projection, the programmed instruction and the computer etc. have not been made available in many public secondary schools in Nigeria.

Research Question 3: What are the state of workshop tools and equipment for teaching and learning basic technology in public secondary schools? 
Table 3

Mean response on the state of workshop tools and equipment for teaching and learning of basic technology in public schools.

\begin{tabular}{|c|c|c|c|c|c|}
\hline Items & $\mathrm{X}$ & Agree & $\%$ & Disagree & $\%$ \\
\hline $\begin{array}{l}\text { The workshop is equipped with modern tools } \\
\text { and equipment such as lathe, shaping and } \\
\text { drilling machines, etc. }\end{array}$ & 84 & 11 & 13.09 & 73 & 86.90 \\
\hline $\begin{array}{l}\text { Many public secondary schools still make use } \\
\text { of old workshops built when the school } \\
\text { started. }\end{array}$ & 84 & 70 & 83.33 & 14 & 16.67 \\
\hline $\begin{array}{l}\text { Many teachers sometimes borrow tools such } \\
\text { as screw drivers, pliers, spanners etc. from } \\
\text { the roadside mechanics. }\end{array}$ & 84 & 65 & 77.30 & 19 & 22.62 \\
\hline $\begin{array}{l}\text { Majority secondary school basic technology } \\
\text { workshops have obsolete tools, materials and } \\
\text { equipment. }\end{array}$ & 84 & 68 & 80.95 & 16 & 19.05 \\
\hline $\begin{array}{l}\text { Many public secondary schools do not make } \\
\text { positive moves toward replacing their } \\
\text { outdated tools and equipment found in their } \\
\text { basic technology workshops. }\end{array}$ & 84 & 61 & 72.62 & 23 & 27.38 \\
\hline
\end{tabular}

Table 3 shows the mean response on the state of workshop tools and equipment for teaching and learning of basic technology in public schools. The statistical results shows that the percentage of the respondents that agreed with the items are higher that the percentage of the populations that disagreed with the items. Therefore, the study concludes that the workshop is not well equipped with modern tools and equipment such as lathe, shaping and drilling machines, etc. secondly, that many public secondary schools still make use of old workshops built when the school started. This is in line with the findings of Okolie 2014 that many Nigerian schools still make use of the same workshops built for them during the time such schools were established. In many of such schools, many workshop tools and equipment available till date were the ones bought during the establishment of the schools. This affects the students' performances in basic technology.

Research Question 4: To what extent is the teaching and learning of basic technology in public secondary schools funded?

Table 4

Mean response on the extent of funding for teaching and learning of basic technology in public secondary schools.

\begin{tabular}{|c|c|c|c|c|c|}
\hline Items & $\mathrm{X}$ & Aoree & $\%$ & Disaoree & $\%$ \\
\hline $\begin{array}{l}\text { Majority of the public secondary schools } \\
\text { do not have funds to purchase basic } \\
\text { technology workshop tools and equipment. }\end{array}$ & 84 & 62 & 73.81 & 22 & 26.90 \\
\hline $\begin{array}{l}\text { There is lack of funds to train and re-train } \\
\text { the basic technology teachers for effective } \\
\text { teaching and learning of the subject. }\end{array}$ & 84 & 73 & 86.90 & 11 & 13.06 \\
\hline $\begin{array}{l}\text { Basic technology students are not often } \\
\text { motivated through scholarships due to } \\
\text { lack of funds. }\end{array}$ & 84 & 53 & 63.09 & 21 & 25 \\
\hline $\begin{array}{l}\text { Irregular payment of teachers salary due to } \\
\text { lack of fund hinders effective teaching and } \\
\text { learning of basic technology. }\end{array}$ & 84 & 69 & 82.14 & 15 & 17.86 \\
\hline $\begin{array}{l}\text { Government does not have special funds for } \\
\text { basic technology programme in public } \\
\text { secondary schools. }\end{array}$ & 84 & 64 & 76.19 & 20 & 23.81 \\
\hline
\end{tabular}

Table 4 proved that all the respondents agreed or are in favor of all the items on the extent of funding for teaching and learning of basic technology in public secondary schools. The data revealed that majority of the public secondary schools do not have funds to purchase basic technology workshop tools and equipment. The National Policy on Education (2004) pointed out that the government is aware that only limited equipment and facilities exist for teachers at different levels.

Okoro (1993) made it known that ineffective teaching may be caused by lack of suitable tools, equipment and materials due to inadequate funding. They have to be supplied if remarkable improvement in the performance of students is to be made for the attainment of the carrying capacity needed in the tertiary 
institutions. The nation must therefore look ahead to evolving strategies for meaningful implementation of the present day pre-vocational and technical education, curricula objectives, if the challenges posed by the contemporary needs are to be met. The logical thing to do is to identify the root causes of the ailment and apply appropriate cure (Ofoegbu, 2002). It is no doubt that funding has impeded provision of necessary tools, materials, basic amenities, library, infrastructures etc. in Nigerian public secondary schools. In line with Nwachi (1995), the required impact has not been made in order to maintain and put the Nigerian educational system in proper position to enhance technological development in the country.

According to Obi (2006), funding is the amount of money that has been made available to execute a particular purpose that will be beneficial to the majority of people. He further stressed that basic technology subject is very important in the sense that at the end of the programme, the beneficiaries (students) will be competent and gain enough skills that will help them in the future. Combel (2004) stated that the technology education programme should be well funded because its aspect of education is quite different from other form of education. This line of thought is better reinforced by one of the theories of technology education, which noted that its teaching and learning requires much money/ funds in order to be effective.

The study results also revealed that there is lack of funds to train and re-train the basic technology teachers for effective teaching and learning of the subject. When there is no fund allocated to training or retraining of teachers, they become stagnant in their academic growth and development. And over time, the teachers become outdated and as well run short of knowledge of current trends in basic technology. The training of academic staff is ordinarily a continuous exercise to ensure consistent improvement in the quality of their outputs. The training is in two-fold: training to acquire minimum qualification to teach and continued professional training. Both types of training can be acquired either locally or overseas. According to Ekemede, (2005) usually, local training within the nation is cheaper than overseas training but more strenuous because of inadequate facilities, literature and distractions arising from the need to meet the necessary demands. Overseas training requires a lot of foreign exchange but the enabling environment exists to achieve success in a record time. However, over time it has always been difficult to get the trainees back to their respective countries after the completion of their study. When the teachers are trained /re-trained, the students benefit more and their performances are better.

The respondents agreed that basic technology students are not often motivated through scholarships due to lack of funds. Also irregular payment of teachers salary due to lack of fund hinders effective teaching and learning of basic technology. Many at times, students who perform excellently at the end of school terms are not encouraged through prize giving, awarding of scholarships in Nigerian public schools. This does not motivate the students to even work harder. Secondly, the teachers are most times not paid their salaries as at when due. Some other times, they are not paid at all. This results in teachers embarking on industrial (strike) action. This type of attitude by the government kills the interest of the teachers on imparting the required technological skills to the students.

Government does not have special funds for basic technology programme in public secondary schools. This was agreed by the respondents and it is also in line with the words of Adenle and Alabiyi (2005) that funds have not been specially allocated to technology education and this has lead to inadequate and absolute machine and tools, cheap building constructions as classrooms, poorly trained teachers and non-payment of technology teachers' salaries as well as non-provision of basic services to students such as scholarship and libraries not properly equipped with relevant and adequate materials etc.

\section{Conclusion}

From the findings of this study, the impediments to effective teaching and learning of basic technology in Nigerian public schools includes, poor teaching methods adapted by the basic technology teachers, inadequacy of instructional materials, inadequate workshop tools and equipment needed for effective teaching and learning of basic technology and poor funding of basic technology are the impediments to effective teaching and learning of basic technology as well as the objectives mapped out by the Federal Republic of Nigeria stated in the National Policy on Education 2004.

\section{Recommendations}

Based on the findings of the study, the following recommendations were made:

1. Suitable teaching methods such as demonstration, discussion methods etc should be adopted by the basic technology teachers for effective teaching and learning of basic technology in the Nigerian public secondary schools.

2. The government should erect new school workshops; make provision of modern workshop tools and equipment for effective teaching and learning of basic technology in public schools.

3. Adequate funds should be provided by the governments at all levels to support basic technology programmes in Nigerian public secondary schools. 
4. Basic technology students should be motivated through awarding of scholarships to the best performing students.

5. Basic technology teachers should be paid their salaries at the appropriate time to motivate them.

\section{References}

[1]. Adenle, S. and Olabiyi, O. S. (2005). Funding Technical Eucation for Sustainable Youth Empowerment. Paper presented at the 18 Annual National Conference of Nigerian Association of Teachers of Technology. Rivers.

[2]. Agwu, A. U. (2005). Strategies for Effective Teaching and Learning of Basic Technology, Enugu. Chelston Publishers.

[3]. Combel, H. B. (2004). Cultural Experience of Educational Financing. Illorin. Megraw publisher Ltd.

[4]. Ekemode, K.O. (2000). Enhancement of Agricultural Productivity through Scientific to Agricultural Productivity through Scientific and Technological Development. Introduction to Agricultural for sustainable Development. Nigerian Association of Agricultural Educators. Lagos.

[5]. Eya, P. E.(2006). Roles of Instructional Materials in Improving Quality of Education in Nigeria. Ebonyi State University Journal of Education. 4. (1). 178

[6]. Eya, P. E. And Neboh, O. (2001). Evaluation of the Available Instructional Materials for the Implementation of the UBE Programme in Enugu Education Zone. The Nigerian Universal Basic Education Journal. (1). 2. 27-31.

[7]. Fafunwa, B. A. (2001). Conscious Planning of Educational System. Journal of Educational Research. 5 (2) $32-36$.

[8]. Federal Republic of Nigeria (2004). National Policy on Education (Revised). Lagos; Federal Ministry of Education Press.

[9]. Inyiagu, E. E. (2012). Introduction to Students' Industrial work Experience Scheme (SIWES); A Practical Guide for Successful Industrial Training. Enugu. New Generation Books.

[10]. Lin, Y. N. (2001). Traits Analysis and Influence on High Performing Student in Mechanical Education. Australia. Wales Publishers.

[11]. Nwachi, S. G. (1995). Educational Development and Strategies. Lagos. JUD Publishers.

[12]. Nwani, A. (2005). Fundamentals of Curriculum Development and Planning. Abakaliki. Salt Coast Printing and Publishing Ltd.

[13]. Obi, E. (2006). Funding is an Amount of Money Used to Produce Vocational Equipment. A Reference Manual.

[14]. Ofoegbu, L. (2002). Principles and Concept of Introductory Technology. A Paper Presented on the Vocational Day of Government Secondary School, Gwarinpa. Abuja.

[15]. Ogwa, E.C. (2002). Effective Teaching Methods. Enugu. Cheston Press Ltd.

[16]. Okolie U. C. (2014), Management of Woodwork Workshop in Tertiary Institutions in Nigeria: An Analytical Study. Malaysian Online Journal of Education. 2 (1) 20-36.

[17]. Okoro, O. M. (1993). Principles and Methods in Vocational and Technical Education. Nsukka. University Trust publishers.

[18]. Onwuzurigbo, C. C. (2007). Strategies for Effective Study of Introductory Technology in Junior Secondary Schools In Abakaliki. Unpublished B.Sc. Thesis, Department of Technology and Vocational Education. Ebonyi State University, Abakaliki.

[19]. Uwameiya, O. (2006). Effect of Reciprocal Peer Tutoring on the Academic Achievement of Students in Introductory Technology. Unpublished B.Sc.Ed Thesis. Department of Technology and Vocational Education. Ebonyi State University. Abakaliki. 